\title{
INCIDENCE OF PRIMARY LUNG CANCER IN INDIA
}

\author{
BY \\ R. VISWANATHAN, SEN GUPTA, AND P. V. KRISHNA IYER \\ From the Vallabhbhai Patel Chest Institute, University of Delhi, and the Defence Science Laboratory, \\ Metcalf House, Delhi
}

(RECEIVED FOR PUBLICATION JULY 11, 1961)

While fairly accurate data for mortality rate and less reliable figures for morbidity rate for lung cancer are available in many Western countries, we have no such information in India. The reasons for this are obvious. In the first place, there is no separate column for lung cancer even in the morbidity returns regarding hospital admissions of the different States in the country. Secondly, it is a fact that even to-day there is no reliable machinery for the collection of vital data in India. Paucity of reliable reports regarding the incidence of lung cancer in India has led to the erroneous impression in other countries that the disease is rare in India. Doll (1953) has quoted Nath and Grewal (1935) and Gharpure (1948) as evidence of the extreme rarity of the disease. Banker (1955) has, however, corrected the statement made by Gharpure and shown that 22 cases in Gharpure's series which were shown to have chest cancer had in fact primary carcinoma of the lung. Banker studied necropsy data of 43 cases of lung cancer among 9,210 consecutive necropsies and showed that primary cancer of the lung constituted $14.4 \%$ of cancer in all sites. Sirsat (1958) reported that at the Tata Memorial Hospital primary cancer of the lung constituted $1 \%$ of all malignant tumours. Because there is a growing impression amongst physicians and surgeons that lung cancer is on the increase, a comprehensive epidemiological study is undoubtedly indicated. The data presented here are intended to give a rough idea of the incidence of lung cancer in India and its possible increase during recent years. The figures have been collected from teaching hospitals and cancer institutes since adequate diagnostic facilities are available only in those institutions. In the absence of a systematic survey, we have to depend on hospital statistics and necropsy data to assess the incidence of the disease.

\section{Methods AND Material}

The senior author (R.V.) initiated the collection of data in regard to lung cancer some time in the middle of 1959 by sending a circular letter and questionnaire to all the administrative medical officers and the heads of teaching hospitals (Table I).

TABLE I

VALLABHBHAI PATEL CHEST INSTITUTE. QUESTIONNAIRE ON THE INCIDENCE OF BRO VCHO GENIC CARCINOMA IN INDIA

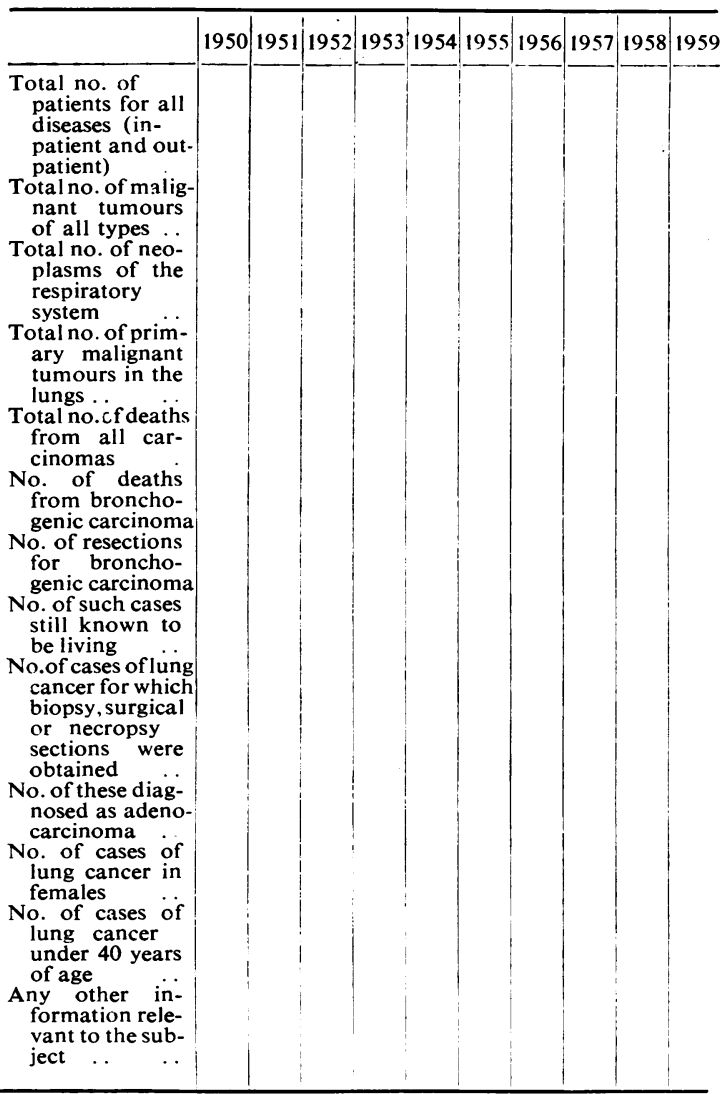


Personal visits were also made to hospitals in Delhi and to the teaching hospitals in Lucknow, Calcutta, Bombay, and Madras to facilitate the collection of information and verification of the data supplied. The material was analysed by one of us (P.V.K.) and statistically evaluated.

\section{RESULTS}

The data collected from different hospitals in India for the years 1950-59 are given in Table II. Of the 2,444 patients diagnosed as suffering from

TABLE II

INCIDENCE OF LUNG CANCER 1950-59. DATA FROM 15 TEACHING HOSPITALS IN INDIA

\begin{tabular}{|c|c|c|c|c|c|c|}
\hline \multirow[b]{2}{*}{ Year } & \multicolumn{2}{|c|}{ Patients Suffering from } & \multicolumn{4}{|c|}{$\begin{array}{l}\text { Cases of Primary } \\
\text { Malignancy in Lungs }\end{array}$} \\
\hline & $\underset{\text { Diseases }}{\text { All }}$ & $\begin{array}{c}\text { Malignant } \\
\text { Tumours } \\
\text { of All } \\
\text { Types }\end{array}$ & Male & Female & Total & $\begin{array}{c}<40 \\
\text { Years } \\
\text { of Age }\end{array}$ \\
\hline $\begin{array}{l}1950 \\
1951 \\
1952 \\
1953 \\
1954 \\
1955 \\
1956 \\
1957 \\
1958 \\
1959\end{array}$ & $\begin{array}{l}2,229,324 \\
1,710,977 \\
2,318,001 \\
2,780,551 \\
3,791,210 \\
5,918,047 \\
7,519,507 \\
6,826,368 \\
7,260,864 \\
7,290,794\end{array}$ & $\begin{array}{r}3,499 \\
4,145 \\
6,951 \\
7,529 \\
7,037 \\
13,006 \\
13,929 \\
17,030 \\
19,704 \\
18,520\end{array}$ & $\begin{array}{r}47 \\
50 \\
96 \\
86 \\
80 \\
248 \\
303 \\
363 \\
440 \\
420\end{array}$ & $\begin{array}{r}12 \\
7 \\
14 \\
11 \\
8 \\
30 \\
53 \\
48 \\
54 \\
74\end{array}$ & $\begin{array}{r}59 \\
57 \\
82 \\
97 \\
97 \\
278 \\
356 \\
411 \\
494 \\
499\end{array}$ & $\begin{array}{r}9 \\
4 \\
9 \\
19 \\
9 \\
28 \\
33 \\
32 \\
34 \\
42\end{array}$ \\
\hline Total & & & 2,133 & 311 & 2,444 & 219 \\
\hline
\end{tabular}

lung cancer between 1950 and $1959,87.3 \%$ were males and $12.7 \%$ were females. Two hundred and nineteen patients were under 40 years of age and the remaining 2,425 were over 40 .

To facilitate comparison of lung cancer cases in different years, the data have been reduced to a common base and are presented in Tables III and IV and Figs. 1 and 2.

TABLE III

CASES OF LUNG CANCER PER MILLION CASES OF ALL DISEASES, $1950-59$

\begin{tabular}{|c|c|c|c|c|}
\hline Year & Total & Male & Female & $\begin{array}{l}<40 \text { Years } \\
\text { of Age }\end{array}$ \\
\hline $\begin{array}{l}1950 \\
1951 \\
1952 \\
1953 \\
1954 \\
1955 \\
1956 \\
1957 \\
1958 \\
1959\end{array}$ & $\begin{array}{l}26 \cdot 5 \\
33 \cdot 3 \\
41 \cdot 4 \\
34 \cdot 9 \\
25 \cdot 6 \\
47.0 \\
47 \cdot 3 \\
60 \cdot 2 \\
68 \cdot 0 \\
68 \cdot 4\end{array}$ & $\begin{array}{l}21 \cdot 1 \\
29 \cdot 2 \\
35 \cdot 4 \\
31 \cdot 0 \\
23 \cdot 5 \\
41.9 \\
40 \cdot 2 \\
53 \cdot 2 \\
60.6 \\
58 \cdot 3\end{array}$ & $\begin{array}{r}5.4 \\
4.1 \\
6.0 \\
3.9 \\
2.1 \\
5.1 \\
7.1 \\
7.0 \\
7.4 \\
10.1\end{array}$ & $\begin{array}{l}4 \cdot 0 \\
2 \cdot 3 \\
3.9 \\
6 \cdot 8 \\
2.4 \\
4 \cdot 7 \\
4.4 \\
4 \cdot 7 \\
4.7 \\
5.7\end{array}$ \\
\hline
\end{tabular}

There is a significant rise in the number of cases of lung cancer even during the ten years 1950 to 1959, and although the incidence is increased in both sexes, that in males is greater than that in females (Fig. 1). This has also been observed by workers in other countries. Fig. 2 shows a significant increase of lung cancer as compared to malignant tumours of all types.
TABLE IV

CASES OF LUNG CANCER PER THOUSAND CASES OF CANCER, ALL SITES, 1950-59

\begin{tabular}{|c|c|c|c|c|}
\hline Year & Total & Male & Female & $\begin{array}{c}<40 \text { Years } \\
\text { of Age }\end{array}$ \\
\hline $\begin{array}{l}1950 \\
1951 \\
1952 \\
1953 \\
1954 \\
1955 \\
1956 \\
1957 \\
1958 \\
1959\end{array}$ & $\begin{array}{l}16.9 \\
13.8 \\
13.8 \\
12.9 \\
13.8 \\
21.4 \\
25.6 \\
24.1 \\
25.1 \\
26.9\end{array}$ & $\begin{array}{l}13.5 \\
12.1 \\
11.8 \\
11.4 \\
12.7 \\
19.1 \\
21.8 \\
21.3 \\
22.4 \\
22.9\end{array}$ & $\begin{array}{l}3.4 \\
1.7 \\
2.0 \\
1.5 \\
1.1 \\
2.3 \\
3.8 \\
2.8 \\
2.7 \\
4.0\end{array}$ & $\begin{array}{l}2.6 \\
1.0 \\
1.3 \\
2.5 \\
1.3 \\
2.2 \\
2.4 \\
1.9 \\
1.7 \\
2.3\end{array}$ \\
\hline
\end{tabular}

The distribution according to age of 1,570 cases of lung cancer seen during 1955-59 is shown in Fig. 3. The largest number, namely, 780 cases (or $45 \%$ of all cases), are in the age group 50-60 (Table V). The total number of cases increased from 250 in 1955 to 356 in 1958.

TABLE V

DISTRIBUTION OF 1,570 CASES OF LUNG CANCER, 1955-59, BY AGE

\begin{tabular}{c|c}
\hline Age (yr.) & No. of Cases \\
\hline$<30$ & 40 \\
$30-39$ & 106 \\
$40-49$ & 406 \\
$50-59$ & 708 \\
$60-69$ & 229 \\
$70-$ & 81 \\
\hline Total & 1,570 \\
\hline
\end{tabular}

Information about 95 necropsies for lung cancer was obtained for the period 1950-59 and is given in Table VI. The histological types of tumour in these 95 cases are given in Table VII.

TABLE VI

NECROPSIES PERFORMED ON LUNG CANCER CASES,

\begin{tabular}{lll|c}
\hline & & & No. of Necropsies \\
\hline Total & $\ldots$ & $\ldots$ & 95 \\
Females & $\ldots$ & $\ldots$ & 17 \\
Males & $\ldots$ & $\ldots$ & 78 \\
Smokers & $\ldots$ & $\ldots$ & $64(67.6 \%)$ \\
Non-smokers &.. & $31(32.4 \%)$ \\
\hline
\end{tabular}

TABLE VII

DISTRIBUTION OF TUMOURS BY HISTOLOGICAL TYPE IN 95 NECROPSIES FOR LUNG CANCER, 1950-59

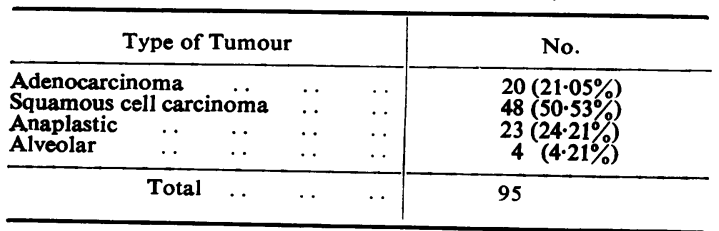




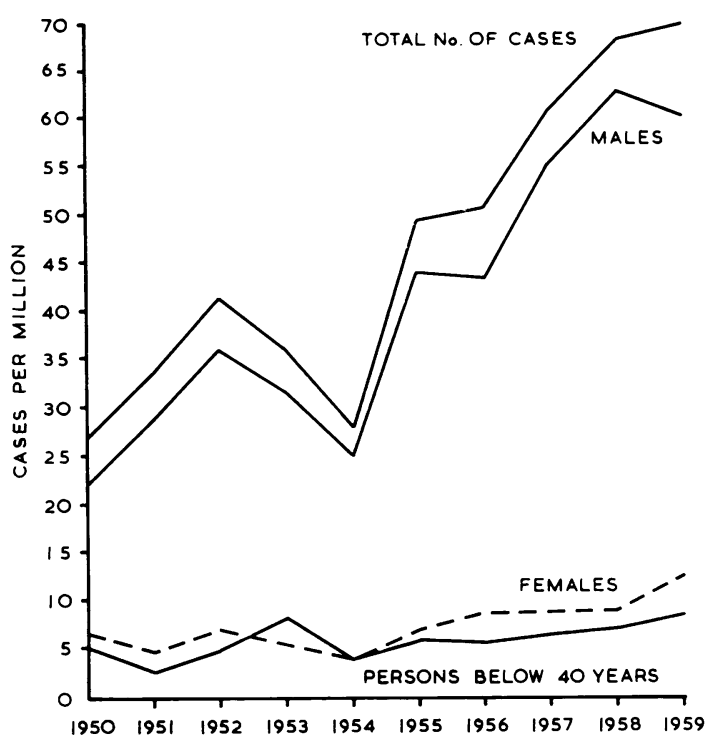

FIG. 1.-Total number of cases, males, females, and patients under 40 , suffering from primary lung cancer per million total hospital admissions, 1950-59.

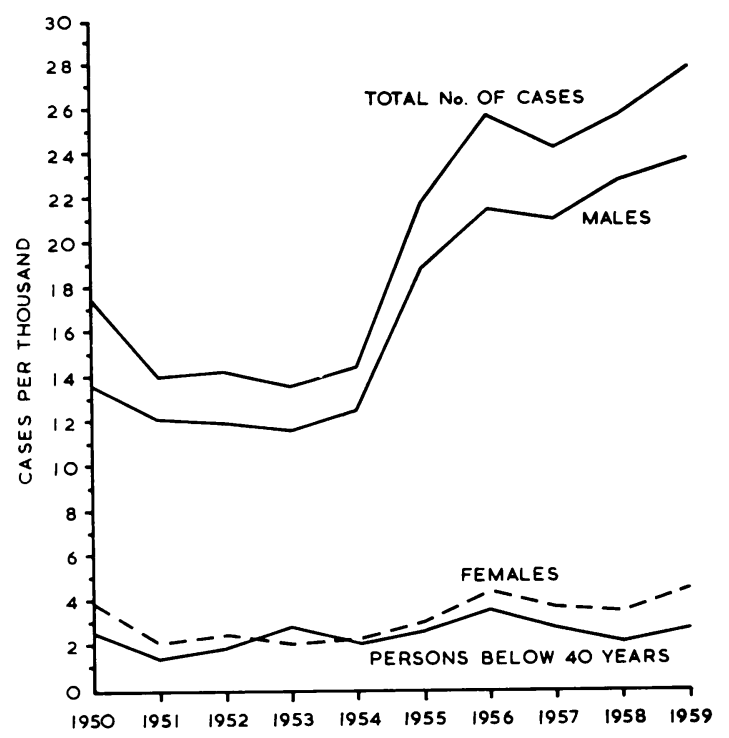

FIG. 2.-Total number of cases, males, females, and patients under 40 , suffering from primary lung cancer per thousand cases of malignant tumours of all types.
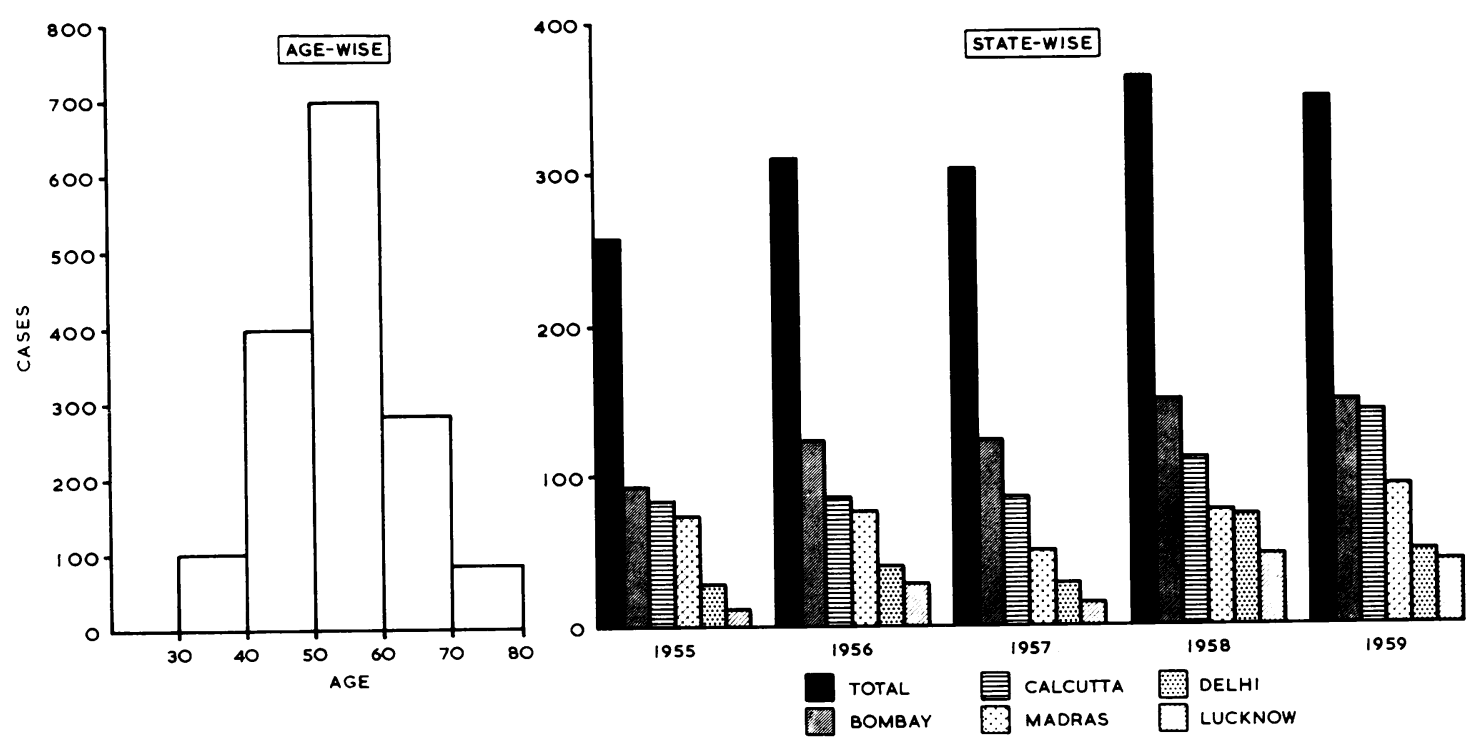

FIG. 3.-Distribution according to age and State of 1,570 cases of lung cancer, 1955-59. 
Table VIII gives the histological types as reported by different authors. The incidence of types seen in India is more or less the same as that seen in other countries. This is especially noticeable in epidermoid and undifferentiated cancers.

Age distribution is given in Table IX, 38 cases falling within the age group 50-59 years.

TABLF, VIII

DISTRIBUTION OF TUMOURS BY HISTOLOGICAL TYPE, COMPARED WITH OTHER REPORTS

\begin{tabular}{|c|c|c|c|c|c|c|}
\hline \multirow[b]{2}{*}{ Author } & \multirow[b]{2}{*}{ Country } & \multirow{2}{*}{$\begin{array}{l}\text { Total } \\
\text { No. of } \\
\text { Cases }\end{array}$} & \multicolumn{4}{|c|}{$\begin{array}{c}\text { Histological } \\
\text { Type of Carcinoma }\end{array}$} \\
\hline & & & $\begin{array}{l}\text { Alveo- } \\
\text { lar }\end{array}$ & $\begin{array}{l}\text { Adeno- } \\
\text { carci- } \\
\text { noma }\end{array}$ & $\begin{array}{l}\text { Epider- } \\
\text { moid }\end{array}$ & $\begin{array}{l}\text { Undif- } \\
\text { feren- } \\
\text { tiated }\end{array}$ \\
\hline & & & $(\%)$ & $(\%)$ & $(\%)$ & $(\%)$ \\
\hline Olson (1935) & U.S.A. & 69 & - & $24 \cdot 0$ & $43 \cdot 0$ & $33 \cdot 0$ \\
\hline $\begin{array}{l}\text { Tanner and } \\
\text { Gordon (1952) }\end{array}$ & U.S.A. & 35 & - & $3 \cdot 0$ & $51 \cdot 0$ & $46 \cdot 0$ \\
\hline$\underset{(1951)}{\text { McDonald et } a l .}$ & U.S.A. & 849 & - & $13 \cdot 2$ & $37 \cdot 8$ & $49 \cdot 0$ \\
\hline $\begin{array}{l}\text { Doll and Hill } \\
(1952)\end{array}$ & U.K. & $\begin{array}{l}1.357 \\
(\mathrm{M})\end{array}$ & - & $4 \cdot 0$ & $52 \cdot 0$ & $44 \cdot 0$ \\
\hline & & $\begin{array}{l}108 \\
(\mathrm{~F})\end{array}$ & & $13 \cdot 0$ & $23 \cdot 0$ & $64 \cdot 0$ \\
\hline Banker (1955) . . & India & 43 & - & $28 \cdot 0$ & $7 \cdot 0$ & $65 \cdot 0$ \\
\hline Sirsat (1958) & India & 100 & - & $20 \cdot 0$ & $75 \cdot 0$ & $5 \cdot 0$ \\
\hline Present study & India & 95 & $4 \cdot 2$ & $24 \cdot 2$ & $50 \cdot 5$ & $21 \cdot 1$ \\
\hline
\end{tabular}

TABLE IX

DISTRIBUTION OF 95 NECROPSIES FOR LUNG CANCER BY AGE

\begin{tabular}{c|c}
\hline Age $(\mathrm{yr})$. & No. \\
\hline 30 & 3 \\
$30-39$ & 11 \\
$40-49$ & 19 \\
$50-59$ & 38 \\
$60-69$ & 19 \\
$70-79$ & 3 \\
$80-$ & 2 \\
\hline Total & 95 \\
\hline
\end{tabular}

\section{Discussion}

From time to time cases of lung cancer from various sources have been analysed by different workers. They have concluded that an increase in the incidence of lung cancer is real and is due to one or more environmental factors. Others have questioned the reliability of the data and consider that the increase is only apparent, due to improvements in diagnostic facilities and an expansion of the medical services. Clemmesen, Nielsen, and Jensen (1953) attribute the divergence of opinion to the fact that materials for analysis have nearly always been collected from hospitals or medical centres serving populations of unknown delimitation. In order to establish a proof of the reality of the increase in the incidence of lung cancer and to open the way for further research, they emphasize the need to study a population that is delimited and of sufficient size, uniform and fairly stationary, socially, economically and with regard to living space. Medical facilities of the best quality should be equally accessible to all social strata of the population and statistical facilities should be of a correspondingly high standard. The establishment of a cancer registry in Denmark in 1942 has made accurate data available regarding the incidence of lung cancer.

The data that have been presented here, in spite of their unavoidable incompleteness, have provided sufficient information to strengthen the general impression that lung cancer is on the increase in India though not to the same extent as it is in many western countries. We shall be satisfied if the information presented will stimulate sufficient interest in those authorities who can sponsor a more comprehensive study of the endemiology of primary carcinoma of the lung in India.

\section{SUMMARY}

Data regarding the incidence of lung cancer were obtained from teaching hospitals in India for the years 1950-59.

Necropsy data of 95 cases were also obtained.

Statistically analysed results are given.

There is evidence to show that, even though the incidence of lung cancer is not high in India when compared with that in most western countries, there has been a definite increase in the incidence of lung cancer during the last ten years.

A more comprehensive study of the epidemiology of the disease in India is strongly warranted.

\section{REFERENCES}

Banker, D. D. (1955). J. postgrat. Me.l., 1. 108.

Clemmesen, J Nielsen, A., and Jensen, E. (1953). In Cancer of the Lung (Endemiology), p. 177, ed. J. Clemmesen.

Doll, R. (1953). Brit. med. J., 2, 521.

- and Hill, A. B. (1952). Ibid., 2, 1271.

Gharpure, P. V. (1948). Indian med. Gaz., 83, 5.

McDonald, J. R., McBurmey, R. P., Carlisle, J. C., and Patton, M. D. (195i). J. thorac. Surg., 22, 62 .

Nath, V., and Grewai, K. S. (1935). Indian J. med. Res., 23, 149.

Olson, K. B. (1935). Amer. J. Path., 11, 449.

Sirsat, M. V. (1958). J. posigrad. Med., 4, 6 .

Tanner. G. R., and Gordon, H. (1952). Amer. J. Path., 28, 953. 